AN EXAMINATION OF GENDER EFFECTS ON THE

CAREER SUCCESS OF INFORMATION SYSTEMS EMPLOYEES

Jack J. Baroudi

Magid Igbaria

Working Paper series

STERN IS-93-17 


\title{
AN EXAMINATION OF GENDER EFFECTS ON THE CAREER SUCCESS OF INFORMATION SYSTEMS EMPLOYEES
}

\author{
Jack J. Baroudi \\ Associate Professor \\ Information Systems Department \\ Stern School of Business \\ New York University \\ 44 West 4th Street, Room 9-73 \\ New York, NY 10012 \\ 212-998-0804 \\ Magid Igbaria \\ Professor \\ Department of Management \\ College of Business and Administration \\ 32nd \& Chestnut Streets \\ Philadelphia, PA 19104 \\ 215-895-2143
}

June 1993 


\title{
AN EXAMINATION OF GENDER EFFECTS ON THE CAREER SUCCESS OF INFORMATION SYSTEMS EMPLOYEES
}

\begin{abstract}
In this paper we examined the differences and similarities in the human capital variables of male and female information system (IS) workers and the affect these differences had on job outcomes. The human capital variables studied included: age, education, organization and job tenure, and number of years in the IS occupation. We found that, even when controlling for the differences in human capital, women in IS still tended to be employed at lower levels of the organization, made less money, and had greater intentions to leave the organization.
\end{abstract}




\section{EXAMINATION OF GENDER EFFECTS ON CAREER SUCCESS OF INFORMATION SYSTEMS EMPLOYEES}

The number of women entering the workforce has grown considerably in recent years. It has been projected that by the year 2000 approximately 47 percent of the workforce will be female, and 61 percent of all women of working age will have jobs (Johnston, 1987). Women are also expected to comprise about three fifths of the new entrants into the labor force in this decade. However, women are, and continue to be underrepresented in the information systems field, especially in positions of power and responsibility. Women make up 30 percent of computer scientists and comprise only 32 percent of systems analysts, 35 percent of computer programmers, 10 percent of IS directors, 18 percent of project leaders, and 14 percent of applications development managers (Frenkel, 1990; Goff, 1992; Johnson, 1990a).

There are two related concerns regarding the under representation of women in computing (Pearl, et al., 1990). First, the restricted participation of women in the field of computing may indicate that practices within the field discourages or prevents women from entering or remaining in the profession. These barriers may include male-biased educational programs, and a male-dominated computer "culture". In these cases, and others, women are directed away from the computer industry. Second, the projected demographic shifts in the workforce may produce a severe shortage of computer personnel, unless the participation of women and other underrepresented groups, such as blacks, in the occupation increases significantly.

Although research has identified work and individual factors contributing or impeding the participation and career success of minorities in the computing field (Igbaria \& Wormley, 1992; Johnson, 1990a; 1990b; Laberis, 1992; Marenghi, 1992; Morrison, et al., 1987; Terborg, 1977), there is little specific empirical research on the obstacles faced by women in the computing field. A number of studies have suggested that minorities, including women, do not fit into the conventional "organizational mold," and as such experience less favorable work outcomes and lower quality of worklife than white males (Ford, 1985; Igbaria \& Wormley, 1992; 
Kanter, 1977). It was reported that women and minority groups may be differentially treated in some of the tangible work experiences, such as promotion, salary raises, termination, and layoffs (llgen \& Youtz, 1986). Some of these experiences may affect their performance and productivity, satisfaction, loyalty, and their decision to stay or leave the organization. Beyond the issue of equality and social justice, if women in the IS occupation are being treated differently from their male counterparts which causes them to leave an organization or affects their performance then this is a serious problem which must be addressed.

It is generally recognized that IS employees represent a valuable resource critical to the successful implementation and use of sophisticated information technology in organizations (Amoroso, et al. 1989; Baroudi, 1985; Keen, 1991; Niederman, Brancheau \& Wetherbe, 1991; Watson, 1990). Outlining the critical issues facing the IS profession in the 1990's, Niederman, et al.(1991) identified human resource management as one of the areas requiring immediate attention. It was ranked as the fourth most important issue facing the IS field. Further, a recent survey of IS executives reported that improving IS human resources jumped to fifth place from 13th in 1991 (Champy, 1992).

In general, IS personnel management is likely to become even more critical due to the perennial turnover problem, the high costs of recruiting and training, the chronic shortage of new entrants, and the growth in demand for IS employees (Couger, 1988; Laudon \& Laudon, 1992). IS employees have historically displayed a disturbingly high rate of turnover that reached nearly 20 percent in 1987 (Connolly, 1988; Laudon \& Laudon, 1992), and is about twice the average for business managers and professionals (Ludlum, 1988). Employee turnover, although not the only contributor to escalating costs, does play a significant role. Beyond the obvious implication of the direct costs associated with it, there are secondary ramifications to be considered. For example, the constant replacement of personnel could produce a disproportionate ratio of employees in the "introductory" stages of the learning curve instead of the more productive "maturity" stages. And, those employees remaining within the IS department could become somewhat demoralized as a result of an organizational 
malaise that occurs when turnover becomes excessive. Depending on the physical isolation of the IS department, there could even be spin-off morale problems in other departments. Thus, there is a growing need to control the volume of voluntary turnover actions of IS employees.

Most of the research in the MIS field examining IS personnel has tended to view study populations as homogeneous entities in which distinctions of gender are either ignored or considered as irrelevant (Baroudi, 1985; Guimaraes \& Igbaria, 1992; Igbaria \& Greenhaus, 1992). The potential problems raised by the lack of affirmative action and by the historical patterns of discrimination against women and minorities, and the projected demographic changes in the workforce, has been discussed within the professional literature (Fisher, 1992; Johnson, 1990a; 1990b; Laberis, 1992; Liedman, 1992; Marenghi, 1992; Perry, 1992), in most instances, this work has been based upon subjective and anecdotal accounts rather than empirical analysis.

While there is considerable research in the organizational and management literatures focusing on career success variables (these have been defined to include job satisfaction, organizational commitment, intention to stay, salary, organization level, promotability etc.) and while we are aware of the role that gender plays within organizational systems, there is very little known about empirical factors that can be used to explain, as well as predict career success among females and/or minority groups in the information technology field (Igbaria \& Wormley, 1992). Specifically, the primary purpose of this study is to examine the role gender plays in career success within the IS occupation.

\section{GENDER DIFFERENCE THEORETICAL PERSPECTIVES}

Research based in economics and sociology has proposed that wage inequalities and career success outcomes result from differences: in men and women's human capital, the industrial sectors and the type of firms women are employed in, the predomination of women in certain occupational categories and jobs, and other contextual factors (Auster, 1989; Larwood, et al., 1984; Truman \& Baroudi, 
1992). This research attempts to explain gender differences by emphasizing differences in voluntary decisions of individuals or in access or treatment discrimination. In this paper we will use the sociological paradigm to frame our argument for why gender differences in career success exist. We will use the human capital paradigm (drawn from the economics literature) to generate the factors which must be controlled for before we can attribute differences in organizational outcomes to differential treatment of personnel due to gender.

\section{The Sociological Paradigm}

The sociological paradigm highlights the role that industry and labor market conditions play in the allocation of wages to men and women (Auster, 1989). It is suggested that men and women tend to be employed in different occupations, with women heavily concentrated in the lower paying administrative support, staff (including clerical) and service occupations. Men, on the other hand, are heavily represented in executive, administrative, and managerial positions. It was also found that when women do enter male-dominated positions, in business, and make it into middle management and beyond, this is most likely to occur in female-dominated industries, such as health care, education, or personnel/labor relations. These categories of firms pay less than the large, private, productive, profitable, capital intensive corporations (Holusha, 1991; U.S. Department of Labor, 1989).

This paradigm also employs the dual labor market concept. This concept suggests that the job market consists of a set of better, or primary, jobs and a set of worse, or secondary, jobs. Since firms tend to attach wage rates to occupational categories rather than to individuals, employers can pay women less only by assigning them to lower-paid (secondary) job categories and/or by assigning lower values to predominantly female jobs. From research we know women and minorities are disproportionately employed in lower levels or in staff (vs. line) functions that are lower-paying, lower status, less lucrative specialties, out of the mainstream of the business and which don't lead to top management positions (Jones, 1986; Larwood \& Gattiker, 1987; Powell, 1988). 
The sociological paradigm also suggests that two types of groups exist in organizations - identity groups (based on race, religion, ethnicity, gender, marital status, or age) and organization groups (based on organizational level, occupation, work experiences, and common work tasks) (Alderfer, 1986; Morrison \& Von Glinow, 1990; Thomas \& Alderfer, 1989). Individuals who are not in the identity group in power often have fewer opportunities for interesting and challenging work that develop job-related skills and enhance motivation. For example, Kanter (1977) pointed out that women and minorities are "tokens" with few characteristics of the typical top management identity group and therefore have reduced access to opportunity and power within organizations. She views opportunities as growth prospects stemming from the present job and suggests that employees with restricted opportunities ultimately lower their aspirations and commitment, and engage in behaviors that reinforce negative opinions about their potential contributions to the organization and eventually are more likely to leave the organization. Additionally, restricted access to power - through routine task assignments or exclusion from informal social networks produces a cycle of disadvantage for minorities who are unable to influence organizational actions or the course of their own careers.

Other aspects of the sociological paradigm focuses on the individual's relationships with others in the organization and includes such issues as coaching, networking, sponsorship and mentoring. It is argued that women and minorities may be less likely to have supervisory or peer coaching, counseling, mentoring, sponsorship, and/or networking (minorities are often excluded from informal set of contacts and channels of communications), and therefore, will less likely derive the benefits that these opportunities provide (Cabezas, et al., 1989a; Fisher, 1992; Ilgen \& Youtz, 1986; Liedman, 1992; Perry, 1992; Thomas \& Alderfer, 1989). Finally, it is also suggested that executives who had mentors or sponsors earned more money at a younger age and were more satisfied with their work (Greenhaus, et al., 1990; Kanter, 1977; Roche, 1979). This paradigm suggests, therefore, that women in the IS occupation, a traditionally male dominated occupation, will experience differential (and in most cases worse) career outcomes when compared to men. 


\section{The Human Capital Paradigm}

This second paradigm attempts to explain continued gender and racial discrimination by suggesting that individuals are rewarded in their current jobs for their investment in education and job training (Blau \& Ferber, 1987). Specifically, it is assumed that women accumulate less human capital (i.e., knowledge and skills derived from on-the-job training and continuous work experience) than men which accounts for most of the disparity in outcomes. The paradigm suggests that women choose not to invest in accumulating as much human capital (e.g., by investing in less education and/or focusing on less demanding jobs) because they anticipate a lower return on their investment due to career interruptions (due primarily to family and child care responsibilities). Therefore, the human capital explanation focuses on the voluntary choices made by individuals in allocating investment, such as time and effort, to work and family and assumes that investment pays off equally regardless of race or gender. However, recent studies suggest that investment yields greater returns for white men than for women and minorities, irrespective of work efforts and skills: It was reported that discrepancies in organizational level and pay of women and minority groups could not be fully explained by education (Blau \& Ferber, 1989; Cabezas, et al., 1989a; Larwood, et al., 1988; Madden 1985). Blau and Ferber (1989) reported that "it takes considerably more years of schooling for women to achieve the same earnings as men," (p. 44). Further, a survey of Asian- American professionals and managers indicated that education and work experiences yield lower returns in promotion and advancement than for white males (Cabezas, et al., 1989b). Thus, while some of the inequality can be explained as a consequence of the differences in human capital formation the remaining discrepancies may be attributed to other factors, including treatment discrimination and other discriminatory practices (Olson \& Frieze, 1987). What this paradigm does, is provide us with a list of factors other than gender which must be controlled for before we can attribute differences to gender effects. These variables include: age, education, and experience. 


\section{PROPOSED RELATIONSHIPS AND EFFECTS}

\section{The Relationship of Gender and Demographics}

Since women have tended to withdraw from the educational pipeline earlier than men (Pearl, et al., 1990) and entered the IT field in large numbers only in the 1980 s, women in the IT workplace are likely to be much younger, less educated, and have a shorter tenure in the technology field, the job, and the organization than men. Empirical studies reported that women were less educated than men in most countries including Japan, Latin America, Switzerland, Sweden and others (Black, et al., 1992). Therefore we expect:

H1: Women in IT will be younger than men on average

H2: Women in IT will have, on average, lower levels of education than men

H3: Women in IT will have, on average, less organizational tenure than men

H4: Women in IT will have, on average, less job tenure than men

H5: Women in IT will have, on average, fewer years in the IS field than men

The Impact of Gender on Career Success Variables

The sociological paradigm attempts to explain gender differences in job characteristics using the dual labor market concept, where women are mostly associated with the secondary labor market which consists largely of professional and nonmanagerial positions. Empirical data regarding the IT workforce from the Department of Labor (Johnson, 1990a; 1990b; U.S. Department of Labor, 1989) indicate women are overrepresented in some types of lower-level jobs (e.g., programmers, operators) and underrepresented in higher-level jobs (e.g., project leaders and IS managers). Research has also suggested that women who are 
managers aspire to positions lower in the managerial hierarchy than men. It was also reported that women are less likely to reach top positions mainly because of a lack of experience and due to a concentration in areas that don't lead to top positions (Fisher, 1992; Perry, 1992). According to the human capital paradigm women are likely to receive fewer promotions because they possess less human capital. Other research suggests that women encounter a "glass ceiling" that prevents them from reaching upper levels of management in their organization (Morrison, White \& Van Velsor, 1987). The glass ceiling has been used "to describe a barrier so subtle that it is transparent, yet so strong that it prevents women and minorities from moving up the management hierarchy" (Morrison, \& Von Glinow, 1990, p. 200).

There are different sociological factors contributing to the glass ceiling phenomenon. The sociological paradigm helps in explaining this phenomenon. Since the majority of top executives are males, women are segregated into "women's work" which are jobs with lower status, with lower earnings and limited advancement opportunities. Women who do make it are often perceived as "tokens" by their male counterparts and therefore they feel more isolated, and have difficulty gaining the trust of their male peers, have less access to mentors and sponsors, and are excluded from informal networks. These have an impact on women's upward mobility and success. Since women are more often in the outgroup, they are more likely to miss early job challenge opportunities, promotions and greater salary increases. However, to determine if these differences are a result of human capital differences we will need to control for age, education, organizational tenure, job tenure, and number of years in IS field. We hypothesize:

H6: Women in IT, on average will hold lower-level positions than men even when controlling for age, education, organizational tenure, job tenure, and number of years in the IS field.

H6a: Women in IT, on average will report fewer opportunities for promotion than men even when controlling for age, education, organizational tenure, job tenure, and number of years in the IS field. 
Recent research has confirmed the importance of career experiences - salary and promotability- in promoting high levels of career success (Igbaria \& Greenhaus, 1992). Igbaria and Greenhaus found that salary and promotability are positively related to satisfaction, commitment, and intention to stay with the company. According to the human capital paradigm, men generally have more work experience, education and job training, and fewer career interruptions than women, thereby accruing higher returns in their investment. Further, the sociological paradigm suggest that because of social roles, women tend to occupy positions with lower earnings, reduced job training, and less value and status. Other studies also pointed out that individuals within an organization, including executives, middle managers, professionals, and even customers, have discriminatory preferences for white men in the workplace (Becker, 1957; 1964; 1985). Therefore, an organization hires women only at a wage discount large enough to compensate for the loss of utility or level of discomfort associated with employing them (Blau \& Ferber, 1987; Morrison \& Von Glinow, 1990). Additionally, empirical data indicated that women consistently earn lower salaries across all occupational groups in managerial and professional positions (Devanna, 1987; Dipboye, 1987; Johnson, 1990a; U.S. Department of Labor, 1989). The human capital theory assumes that investment pays off equally for all groups, but recent studies suggests that investment yields higher returns for men than for women (Cabezas, et al., 1989b; Larwood, et al., 1988; Madden, 1985). Drazin and Auster (1987) found substantial wage differences between men and women in managerial positions. Nelton and Berney (1987) also reported that "women at the vice presidential levels and above earn $42 \%$ less than their male peers" (p. 27 ). Computerworld (1993) also found that women in IT earned only 72 percent of their male counterparts in 1992. Again, it will be necessary to control for differences in human capital variables. We hypothesize:

H7: Women in IT, on average, receive lower salaries than men even when controlling for age, education, organizational tenure, job tenure, and number of years in the IS field. 
We also examined the extent of boundary spanning activities involved in the jobs, that is, the opportunity to interact with peers in other departments and organizations. Boundary spanning activities can be a significant source of job power, impact individual's career growth and success, and enhance one's influence and visibility in the organization (Hulin \& Roznowski, 1985). It is also reported that without opportunities to take challenging assignments, women may fall behind men in terms of visibility, social contacts, and knowledge and skill development, or they may internalize negative evaluations and stereotypes and engage in "self-limiting behaviors" - for example, refusing a challenging job assignment or declining an opportunity for additional training and development programs (Ilgen \& Youtz, 1986; Morrison \& Von Glinow, 1990). Based on the sociological paradigm, it was suggested that mentors and sponsors play an important role in individual's career success and tend to choose proteges who are similar to themselves in social background and with whom they can more readily identify. Since women may be less likely than men to have access to mentors and sponsors, and since sponsors and mentors may use their influence to enable their proteges to interact with other groups within the organization and could alleviate most of the barriers and obstacles facing their proteges, women have less opportunities for extra and intraorganizational interactions. Additionally, since women have often settled into the lower paying and lower productivity positions (Taylor \& Ilgen, 1981) and into staff or support positions which require little contact, interaction, and organizational communication, they are not assigned into the mainstream of the organization, and are excluded from formal and informal networks of the corporation's primary operations (Ilgen \& Youtz, 1986; Kanter, 1977). Thus, we expect that women have less opportunities to interact with peers and other members within and outside the organization than men.

H8: Women in IT will have, on average, less opportunities to interact with peers and other members within and outside the organization than men even when controlling for age, education, organizational tenure, job tenure, and number of years in the IS field. 
We anticipate that women will be less satisfied with their jobs, less committed to their organizations, and have fewer intentions to stay with their organizations than their male counterparts. These expectations are mainly based on the sociological paradigm, where self-ratings of job satisfaction and commitment are typically higher and turnover is lower for ingroup members (men) than for outgroup members (women). Further, women are more likely to quit work in high technology fields due to their greater uncertainty regarding their appropriateness to nontraditional jobs. For example, it was reported that turnover among female engineers was twice as high as among men (Fisher, 1992). It was also suggested that educated women are more likely to quit their jobs than men, perhaps because of the greater uncertainties associated with jobs traditionally held by men (Viscusi, 1980). It is also suggested that women are more likely to quit because they often leave the labor market to bear and raise children. It is possible that those women who do marry and have children interrupt their careers and quit their jobs (Schwartz, 1989). Moreover, the economic paradigm suggests that since wives typically earn lower pay than do their spouses and serve as secondary earners, they enter the workforce during periods of temporary economic needs and leave thereafter. Also, as women are more likely to relocate to accommodate their careers to their spouse's, they are less likely to be loyal to their organization and stay with the organization. Thus, it is expected that women will report lower career success. Again, before we can attribute outcome differences to gender we must first control for the human capital variables. We hypothesize that:

H9: Women in IT will be, on average, less satisfied with their job than men even when controlling for age, education, organizational tenure, job tenure, and number of years in the IS field.

H10: Women in IT will be, on average, less committed with their job than men even when controlling for age, education, organizational tenure, job tenure, and number of years in the IS field. 
H11: Women in IT will have, on average, more intentions to leave their job than men even when controlling for age, education, organizational tenure, job tenure, and number of years in the IS field.

\section{METHOD}

\section{Sample and Procedure}

In early 1990, a sample copy of an MIS Career Attitude Survey was mailed to presidents of 20 Mid Atlantic chapters of the Data Processing Management Association. Seven of these chapters agreed to participate in this research project. Each chapter provided the authors with membership mailing lists and a copy of the survey was mailed to each member. The survey was accompanied by a cover letter from the president of the local chapter strongly encouraging participation in the study. A postage-paid envelope was enclosed in which respondents returned their completed surveys directly to the researchers at their university address. Participation was strictly voluntary, and members were assured that individual responses to the anonymous survey would be treated confidentially.

Surveys were mailed to 1,152 DPMA members. Thirty one were returned by the postal service because of incorrect addresses. Four hundred and fourteen completed surveys were received by the researchers for a $36.9 \%$ response rate. The elimination of surveys with missing data as well as surveys from respondents in non-MIS positions resulted in a final sample of 348 IS employees representing a broad cross-section of DPMA chapters in the Mid Atlantic Region. A summary of the demographic characteristics of the sample are presented in Table 1.

\section{Insert Table 1 about here}

\section{Measures}

Demographic items were included in the background information section of the 
survey. Gender was assessed with a fixed-response item ( $1=$ male; $2=$ female $)$. Participants indicated their job titles in an open-ended item. Organizational level consisted of two levels: (1) professionals; or (2) supervisors and managers. Education consisted of six levels from (1) some high school to (6) graduate or professional degree. Age, organizational tenure, job tenure, and tenure in the IS field were all measured in years.

Boundary spanning activities. A three-item scale was developed to assess boundary spanning activities, the degree to which employees interact and communicate with others outside of their departments. Each item (e.g., "assist other units in determining appropriate uses of information technology;" "recommend new applications of information technology to top management") was scored on a five-point scale ranging from (1) not part of my job to (5) a very significant part of my job. The three items were averaged to create the boundary spanning activities score (alpha $=.89$ ).

Career experiences. Salary and promotability were each measured by one item. The measure of salary was based on annual salary in the current position. Categories ranged from (1) below $\$ 25,000$ to (6) $\$ 65,000$ or above. In order to assess promotability, participants were asked to respond to the following item: "How would you rate your chances for promotion to a higher position sometime during your career with the company?" Responses to this item were made on a three-point scale with the following anchors: (1) slight chance for promotion; (2) good chance for promotion; and (3) very good chance for promotion.

Job satisfaction. Job satisfaction refers to the emotional reactions of individuals to their jobs and their job experiences. Job satisfaction was assessed with a three-item scale (Hackman \& Oldham, 1976) reflecting overall satisfaction with the job. Each item (e.g., "Generally speaking I am satisfied with my job") required the respondents to indicate their agreement or disagreement on a five point scale ranging from (1) strongly disagree to (5) strongly agree. Responses to the three items were averaged to produce a total job satisfaction score (alpha $=.70$ ).

Organizational commitment. This variable, defined as the identification with a 
particular organization and the desire to maintain membership in that organization, was measured by an abbreviated version of the Organizational Commitment Questionnaire (OCQ) developed by Porter, Crampon, and Smith (1976). The shorter version of the scale used in this study represents a more "pure" measure of the affective dimensions of commitment to the employing organization. Sample items are "I really care about the fate of my organization;" and "I feel very little loyalty to my organization." The response options to the items ranged from (1) strongly disagree to (5) strongly agree. The items were coded such that high scores reflected greater commitment to the organization. The coefficient of reliability of this measure was 88 .

Intention to stay. This was measured by a single item: "Given everything you know about the company in which you are employed and the type of work you like to do, how long do you think you will continue to work at this company?" The response options were anchored on a time-linked five-point scale ranging from (1) one year or less to (5) eleven years or more or until retirement. The item was scored such that high scores reflected stronger intentions to stay with the organization. Kraut (1975), Parasuraman (1982), and others have attested to the efficacy of a single-item measure of turnover intention.

\section{Data Analyses}

To determine if the demographic variables differed as a function of gender, analysis of variance (ANOVA) and chi-square tests of independence were used. ANOVA was used with the variables measuring age, organizational tenure, job tenure and number of years in the IS field. Chi-square was used to test for differences in educational levels. These analyses will allow us to evaluate hypotheses 1 thorough 5 .

To determine if the career success variables varied as a result of gender it is necessary to control for differences in human capital variables in all analyses so that conclusions regarding gender differences were not confounded by differences in human capital variables. Gender differences in the set of career success variables were examined using analysis of covariance (ANCOVA). In each of the ANCOVA analyses conducted, gender was the independent variable and the human capital 
variables (i.e., age, organizational tenure, job tenure, years in the IS field, and education) were the covariance variables. The dependent variables were career activities and success: job satisfaction, organizational commitment, intention to stay, career advancement, organizational level, boundary spanning activities, and salary. These ANCOVA will allow us to test $\mathrm{H} 6$ through $\mathrm{H} 11$.

\section{RESULTS}

Table 1 show that there are no differences among men and women with regard to education. However, gender differences are observed for all other human capital variables (age, organizational tenure, job tenure and IS tenure). The data revealed that female IS employees in the study were younger (Women $=37.33$ vs. Men $=$ $43.08, F=28.25, p \leq .001$ ) and had less tenure in the organization (Women $=7.56$ vs. Men $=10.22, F=6.44, p \leq .05$ ), less tenure in their current job (Women $=3.58$ vs. Men $=4.87, F=5.62, p \leq .05$ ), and in the IS field (Women $=10.93$ vs. Men=17.22, $F$ $=37.65, p \leq .001)$. These results confirm hypotheses $1,3,4$, and 5 .

\section{Insert Table 1 About Here}

Results of the Chi-Square showed a significant relationship between gender and organizational level $\left(C^{2}=15.89, p \leq .001\right)$, salary $\left(C^{2}=33.58, p \leq .001\right)$, job type $\left(C^{2}=21.15, p \leq .001\right)$, and job classification $\left(C^{2}=19.78, p \leq .001\right)$. As noted earlier, positions were classified as either professional or managerial in nature. Table $1 \mathrm{~b}$ shows that men were predominantly in managerial positions, whereas women were mostly in professional -nonmanagerial positions (54.65 percent). Further, Table 2 shows that men were more likely than women to be project leaders, IS managers, and consultants. On the other hand, women were more likely than men to be programmers and systems analysts. We also classified positions as either technical, managerial or consulting. Table 2 indicates that women were more likely to hold technical jobs, whereas men were more likely to hold managerial jobs. The data in Table 4 reveal that, consistent with Hypothesis 6, the initial gender differences in 
organizational level remained significant even after controlling for the human capital variables.

\section{Insert Table 2 About Here}

Table 3 shows that there was no difference in the number of promotions of women and men during their time with their current organization. In order to assess the promotion rate of men and women, the number of years spent in the current organization was divided by the number of promotions received in the organizations, yielding an index of "average time to promotion." As Table 3 indicates, women had a greater promotion rate than men. However, this difference was no longer significant after controlling for human capital variables (Table 4).

\section{Insert Tables 3 and 4 About Here}

The ANOVA results reported in Table 3 and the Chi-square analysis (Table 1B) showed that men reported a significantly higher salary than women. In order to determine the possible reasons for the gender differences in salary, we re-examined the relationships between gender and salary, controlling for the human capital variables (age, organizational tenure, job tenure, education, and number of years in the IS field). Although these factors did explain a portion of gender differences in current salary, consistent with Hypothesis 7 , the salary differential favoring men remained significant even after controlling for the human capital variables.

Table 4 also shows that there was a significant difference in boundary spanning activities. It is noted that women are less likely than men to interact with individuals outside their departmental boundaries. In support of Hypothesis 8 , gender differences remained after controlling for the human capital variables $(F=8.14, p \leq .01)$. These differences may be understandable to some extent, given the small portion of women who held managerial positions, and their very limited presence in roles such as project leaders, IS managers and consultants. However, the differences remained significant $(F=3.52, p \leq .06)$ even after controlling for organizational level. This may suggest 
that women are not given the opportunities for boundary spanning activities as frequently as men. This is consistent with the sociological paradigm which suggests that women may have less access to networking and mentoring activities. In fact, it has been recommended that women must take the initiative to expand their networking activities in order to increase their visibility and their career opportunities (Johnson, 1990b).

Tables 3 and 4 present the results of the ANOVA and ANCOVA of satisfaction, commitment, and intention to leave. Inconsistent with Hypotheses 9 and 10, neither satisfaction nor commitment was related to gender. There was, however, a significant gender difference in intention to leave, in which women were more likely to leave the organization than men. Table 4 also reveals that, consistent with Hypothesis 11 , the significant difference in intention to leave remained significant even after controlling for the human capital variables.

\section{DISCUSSION}

The results of this study provided support for the prediction that women differ from men in human capital variables and in some of the career success and activities variables. Consistent with five of the first six hypotheses, gender differences were found for five of the six human capital variables examined. Inconsistent with Hypothesis 2, education in our sample was similar for men and women. On the other hand, consistent with Hypotheses 1, 3, 4, and 5, men were on average much older than women, they had longer tenure in the organization and in the current job. However, additional analyses indicated these tenure differences were largely attribute to the younger age of women (37.33 years) compared to the men (43.08).

Therefore, it is important to ask why the women in the present sample were younger and less experienced than men. One possible explanation is an age bias in the response rate of men and women. That is, younger women and older men may have been most likely to respond to the survey. However, it is also possible, and in our opinion more probable, that the age and experience differences observed in this 
sample parallel the differences in the IS field as a whole. The tremendous influx of women into the "male domain" of computers, braving societal and psychological barriers, occurred largely in the 1980's; hence, the relative youth of the women in this study, and their shorter experience in the computing field is not surprising.

Consistent with Hypothesis 6, women are reported to hold lower-level positions than men. The present findings suggest that the limited representation of women in managerial jobs is partially a function of their relative youth and limited period of work experience within IS. Since both women and men reported similar perceptions of the likelihood of further advancement in the organization (Table 4), it appears that they do not perceive any gender bias in promotion decisions. Although this does not mean that it does not exist. For example, it should be noted that the human capital variables do not fully account for gender differences in organizational level. Education and work experiences yielded lower returns in advancement to managerial positions for women when compared to men. Thus, the human capital theory cannot adequately explain differential treatment in management; other factors must also be considered including discriminatory practices.

The need for vigilant monitoring is highlighted by the restricted opportunities for boundary spanning activities reported by the women in our sample. Since participation in boundary spanning activities can enhance visibility in the organization and provide an opportunity to develop critical interpersonal and communication skills, women's restricted activities in this area is a source of concern. It is important that supervisors of information technology employees understand that boundary spanning assignments are developmental experiences for their subordinates.

Since our measure of annual salary was based on salary ranges rather than raw dollar figures, it is impossible to determine the exact discrepancy between men and women's earnings. However, as illustrated in Table 1b, women were clearly underrepresented in the two highest salary categories $(\$ 55,000-\$ 64,999$ and $\$ 65,000$ and above). Moreover, employee age, organizational tenure, job tenure, number of years in the IS field and job status (managerial versus professional) did not fully account for discrepancies in salary. This refutes the human capital explanation 
which assumes that investment pays off equally for all groups. This is disturbing, especially in light of recent reports (Business Week cited in Frenkel, 1990) that even when women start out with comparable pay, their salaries lag 25 percent below that of their male counterparts within ten years. Furthermore, Computerworld (1993) also reported that women in IT earned only 72 percent of their male counterparts in 1992. This indicates the need for employers to examine salary histories and compensation decisions to identify the origin and determinants of salary discrepancies between men and women in similar positions to check for possible gender bias.

There was only marginal support for Hypotheses 9-11, which predicted women will be less satisfied and committed than men and are more likely to leave their current organization. This paper found no significant differences in satisfaction and commitment, but a significant difference in intention to leave. Women are more likely to leave than men. The human capital and the sociological paradigms suggest that the most familiar economic motivation underlying potential male-female quit differences is that women often leave the labor market to bear and raise children. Future research should examine whether they can explain the gender differences in quitting by looking at other factors, such as family constraints and relocation, the presence of discriminatory practices among co-workers and/or supervisors.

\section{CONCLUSIONS}

Although the present study provided interesting findings regarding the careers of women and men in the IS field, additional research is required in a number of areas. As an exploratory and largely descriptive study, our research limited itself to bivariate relationships of gender with human capital variables and career activities and outcomes. Future research should examine whether gender is an independent variable that directly influences the career experiences and outcomes of women and men, or operates as a moderator variable, i. e., that women and men have differential attitudinal and behavioral reactions to similar organizational experiences and practices. Further, research on the career outcomes of women and men in IS should be guided 
by theory as well as relevant empirical research in IS and related occupations. Such research should focus not only on variations in the level of different variables based on gender, but also on the pattern of relationships among the study variables. Future studies should examine the relative contribution of individual differences, family situation variables, organizational practices including organizational career development programs, and interactions among them to variations in the performance, career attainments and success of men and women in IS. Moreover, it is necessary to examine not only the more tangible aspects of the work situation as it relates to men and women, but also explore the possibility of more subtle gender differences in work experiences such as receiving supervisory career support, inclusion in the informal communication network, and acceptance by coworkers and the organization (Greenhaus et al., 1990; Johnson, 1990b). The research agenda should include examination of the determinants of the "external career" success as well as the "internal career" success of women and men in information technology. External career success is typically assessed by such indicators as promotions, changes in job responsibilities, and increased compensation. Internal career success reflects an individual's personal definitions of success, and may include criteria such as work that is challenging and personally satisfying or congruent with one's career orientation. To many women and men it may also include the extent to which job demands and the organization's work-family policies are conducive to maintaining a balance between work and family or personal life.

Finally, although the present research provides a "snapshot" view or balance sheet of the status of women in the IS field, it would be useful to track the experiences and accomplishments of women and men over time in order to gain a better understanding of the similarities and differences in their career paths or routes to career success. This calls for longitudinal research, which will facilitate determination of the causal priority of variables, as well as the development of models of career development applicable to IS and related fields. 


\section{REFERENCES}

Alderfer, C.P. "An Intergroup Perspective on Group Dynamics," in J. Lorsch (Ed.), Handbook of Organizational Behavior, Prentice Hall, Englewood Cliffs, NJ, 1986, pp. $190-222$.

Allen, T.J., and Katz, R. "The Dual Ladder: Motivational Solution or Managerial Delusion?" R \& D Management, Vol. 16, No. 2, April 1986, pp. 185-187. Amoroso, D., Thompson, R. and Cheney, P. "Examining the Duality Role of IS Executives: A Study of IS Issues," Information \& Management, 1989, Vol. 17, No. 1 , pp. 1-12.

Arnold, H.J. and Feldman, D.C., "A Multivariate Analysis of the Determinants of Job Turnover," Journal of Applied Psychology, Vol. 67, 1982, pp. 350-360. Auster, E. "Task Characteristics as a Bridge between Macro and Micro Research on Salary Inequality between Men and Women," Academy of Management Review, Vol. 14, No. 2, April 1989, pp. 173-193.

Baroudi, J. J. "The Impact of Role Variables on IS Personnel Work Attitudes and Intentions," MIS Quarterly, Vol. 9, No. 4, December 1985, pp. 341-356.

Bartol, K.M. "Turnover Among DP Personnel: A Causal Analysis,"Communications of the ACM, Vol. 26, No. 10, October 1983, pp. 807-811.

Becker, G. The Economics of Discrimination. University of Chicago Press, Chicago, IL, 1957.

Becker, G. Human Capital. National Bureau of Economics Research, New York, 1964.

Becker, G. "Human Capital, Effort and the Sexual Division of Labor," Journal of Labor Economics, Vol. 3, 1985, pp. S33-S58.

Bedeian, A.G. and Armenakis, A.A. "A Path-Analytic Study of the Consequences of Role Conflict and Ambiguity," Academy of Management Journal, Vol. 24, No. 2, 1981, pp. 417-424.

Betters-Reed, B.L. and Moore, L.L. "Managing Diversity: Focusing on Women and the Whitewash Dilemma," in U. Sekaran and F.T.L. Leong (Eds.), Womenpower: Managing in Times of Demographic Turbulence. Sage Publications, Newbury 
Park, CA, 1992, pp. 31-58.

Billings, R.S. and Wroten, S.P. "Use of Path Analysis in Industrial/Organizational

Psychology: Criticism and Suggestions," Journal of Applied Psychology, Vol. 63, 1978, pp. 677-688.

Black, J.S., Stephens, G.K. and Rosener, J.B. "Women in Management Around the

World: Some Glimpses," in U. Sekaran and F.T.L. Leong (Eds.), Womenpower:

Managing in Times of Demographic Turbulence. Sage Publications, Newbury

Park, CA, 1992, pp. 223-251.

Blau, F.D and Ferber, M.A. "Occupations and Earnings of Women Workers," in K.S.

K.S. Koziara, M.H. Moskow and L.D. Tanner (Eds.), Working Women: Past,

Present, Future. BNA Books, Washington, DC, 1987, pp. 37-68.

Bluedorn, A.C. "A Unified Model of Turnover From Organizations," Human Relations, Vol. 35,1982 , pp. 135-153.

Brooke, P.P., Russell, D.W. and Price, J.L. "Discriminant Validation of Measures of Job Satisfaction, Job Involvement, and Organizational Commitment," Journal of Applied Psychology, Vol. 73, No. 2, 1988, pp. 139-145.

Cabezas, A., Shinagawa, L.H. and Kawaguchi, G. "Income and Status Differences Between White and Minority Americans: A Persistent Inequality," in S. Chan (Ed.), Persistent Inequality in the United States. Edwin Mellen Press, Lewiston, NY, 1989a.

Cabezas, A., Tam, T.M., Lowe, B.M., Wong, A. and Turner, K. "Empirical Study of Barriers to Upward Mobility of Asian Americans in the San Francisco Bay Area," in G. Nomura, R. Endo, R. Leong and S. Sumida (Eds.), Frontiers of Asian American Studies. Pullman: Washington State University Press, 1989b, pp. 85-97.

Champy, J.A. "Mission: Critical," ClO, January 1992, pp. 18.

Cohen, J. and Cohen, P. Applied Multiple Regression/Correlation Analysis for the Behavior Sciences. Lawrence Erlbaum Associates, Hillsdale, NJ, Second Edition, 1983.

Compton, T.R. "Job Satisfaction Among Systems Personnel," Journal of Systems 
Management, Vol. 38, No. 7, July 1987, pp. 28-31.

Computerworld, "Forecast 1993: In Fact," December 28, 1992/January 4, 1993, p. 1.

Connolly, J. "Study: Crash Hangover Keeps Turnover Low," Computenworld, August 8 , 1988 , p. 57.

Cotton, J.L. and Tuttle, J.M. "Employee Turnover: A Meta-Analysis and Review with Implications for Research," Academy of Management Review, Vol. 11, No. 1, 1986, pp. 55-70.

Couger, J.D. "Motivators vs. Demotivators in the IS Environment," Journal of Systems

Management, Vol. 39, No. 6, June 1988, pp. 36-41.

Couger, D.J. and Zawacki, R.A. Motivating and Managing Computer Personnel, Wiley, New York, NY, 1980.

Devanna, M.A. "Women in Management: Progress and Promise," Human resource Management, Vol. 26, 1987, pp. 469-481.

Dipboye, R.L. "Problems and Progress of Women in Management," in Koziara, M.H.

Moskow and L.D. Tanner (Eds.),Working Women: Past, Present, Future. BNA Books, Washington, DC, 1987, pp. 118-153.

Drazin, R. and Auster, E. "Wage Differences Between men and Women: Performance Appraisal ratings versus Salary Allocation as the Locus of Bias," Human

Resource Management, Vol. 26, No. 2, 1987, pp. 157-168.

Eagly, A.H.Sex Differences in Social Behavior: A Social Role Interpretation. Lawrence Erlbaum, Hillsdale, NJ, 1987.

Fisher, A.B. "Working Women: When Will Women Get to the Top," Fortune, September 21, 1992, pp. 44-56.

Ford, D.L. "Facets of Work Support and Employee Work Outcomes: An Exploratory Analysis," Journal of Management, Vol. 11, No. 3, 1985, pp. 5-20.

Frenkel, K. A. "Women and Computing," Communications of the ACM, Vol. 33, No. 11, November 1990, pp. 34-46.

Ginzberg, M. J. and Baroudi, J. J. "MIS Careers -- A Theoretical Perspective,"

Communications of the ACM, Vol. 31, No. 5, May 1988, pp. 586-594.

Goff, L. "Is There a Computer Gender Gap?" MIS Week, April 2, 1990, p. 29. 
Goldstein, D.K. "The Effects of Task Characteristics on the Work Satisfaction, Job Characteristics, and Role Perceptions of Programmers and Analysts," Journal of Management Information Systems, Vol. 6, No. 1, 1989, pp. 41-58.

Goldstein, D.K. and Rockart, J.F. "An Examination of Work-Related Correlates of Job Satisfaction in Programmer/Analysts," MIS Quarterly, Vol. 8, No. 2, June 1984, pp. $103-115$.

Greenhaus, J.H., Parasuraman, S. and Wormley, W.M. "Race, Organizational Experiences, and Career Outcomes," Academy of Management Journal, Vol. 33, No. 1, March 1990, pp. 64-86.

Guimaraes, T. and Igbaria, M. "The Determinants of Turnover Intentions: Comparing IC and IS Personnel," Information Systems Research, Vol. 3, No. 3, September 1992, pp. 273-303.

Hackman, J.R. and Oldham, G.R. "Motivation Through the Design of Work: Test of a Theory," Organizational Behavior and Human Performance, Vol. 16, 1976, pp. 250-279.

Hackman, J. R. and Oldham, G. R. Work Redesign. Addison-Wesley, Reading, MA, 1980.

Heise, D.R., "Problems on Path Analysis and Causal Inference," in B.F. Borgatta (Ed.), Sociological Methodology, Jossey-Bass, San Francisco, CA, 1969, pp. 38-73.

Holusha, J. "Grace Pastiak's 'Web of Inclusion'," The New York Times, May 5, 1992, Section 3, p. 1, 6.

Hulin, C.L., and Roznowski, M. "Organizational Technologies: Effects on Organizational Characteristics and Individuals' Responses," in L.L. Cummings and B.M. Staw (Eds.), Research in Organizational Behavior, JAI Press, Greenwich, CT, Vol. 7, 1985 (pp. 39-86).

Igbaria, M. "Job Performance Evaluations of MIS Employees: An Examination of Antecedents and Consequences," Journal of Engineering and Technology Management, Vol. 8, 1991, pp. 141-171.

Igbaria, M. and Greenhaus, J. "Determinants of MIS Employees' Turnover Intentions: 
A Structural Equation Model,"Communications of the ACM, Vol. 35, No. 2, February 1992, pp. 34-49.

Igbaria, M. and Wormley, W. "Race Effects on Organizational Experiences and Career Success among MIS Managers and Professionals," MIS Quarterly, 1992 (Forthcoming).

Ilgen, D. R. and Youtz, M. A. "Factors Affecting the Evaluation and Development of Minorities in Organizations," in K. Rowland and G. Ferris (Eds.), Research in Personnel and Human Resource Management: A Research Annual, JAI Press, Greenwich, CT, 1986, pp. 307-337.

Jackson, S.E. and Schuler, R.S., "A Meta-Analysis and Conceptual Critique of Research on Role Ambiguity and Role Conflict in Work Settings," Organizational Behavior and Human Decision Processes, Vol. 36, 1985, pp. 16-78.

Johnson, M. "Women Under the Glass," Computerworld, December 3, 1990a, pp. 93-95.

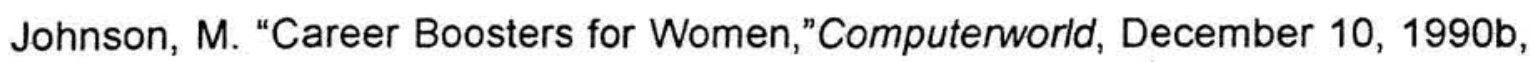
p.95.

Johnston, W.B.Workforce 2000, Work and Workers for the 21st Century. Hudson Institute, Indianapolis, IN, 1987.

Jones, E. "Black Managers: The Dream Deferred,"Harvard Business Review, Vol. 64, No. 3,1986 , pp. 84-93.

Kanter, R.M. Men and Women of the Corporation. Basic Books, New York,NY, 1977. Keen, P.G.W. Shaping the Future. Harvard Business School Press, Boston, MA, 1991 Keller, R.R. and Holland, W.E., "Boundary Spanning Roles in a Research and

Development Organization: An Empirical Investigation," Academy of Management Journal, Vol. 18, No. 2, June 1975, pp. 388-393.

Kerlinger, F.N. and Pedhazur, E.J. Multiple Regression In Behavioral Research. Holt, Rinehart and Winston, Inc., New York, NY, 1973.

Kraut, A.I. "Predicting Turnover of Employees from Measured Job Attitudes," Organizational Behavior and Human Performance (13), 1975, pp. 24-33. Laberis, B. "Barrier Breaker: Katherine Hudson," Computerworld, June 22, 1992, p.20. 
Lanwood, L. and Gattiker, U.E. "A Comparison of the Career Paths Used by Successful Women and Men," in B.A. Gutek and L. Larwood (Eds.), Women's Career Development. Sage Publications, Newbury Park, CA, 1987, pp. 129-156. Larwood, L., Gutek, B.A and Gattiker, U.E. "Perspective on Institutional Discrimination and Resistance to Change," Group and Organizational Studies, Vol. 9, 1984, pp. 333-352.

Larwood, L., Szwajkowski, E. and Rose, S. "Sex and Race Discrimination Resulting from Manager-Client Relationships: Applying the Rational Bias Theory of Managerial Discrimination," Sex Roles, Vol. 18, 1988, pp. 9-29.

Laudon, K.C. and Laudon, J.P. Management Information Systems: A Contemporary Perspective. Second edition, Macmillan Publishing Company, New York, 1992. Liedman, J. "What Women Want," Business Philadelphia, December 1992, pp. 47-51, 77.

Liou, T.K., Sylvia, R.D. and Brunk, G. "Non-Work Factors and Job Satisfaction Revisited," Human Relations, Vol. 43, No. 1, 1990, pp. 77-86.

Locke, E., "The Nature and Causes of Job Satisfaction," in M.D. Dunnette (Ed.), Handbook of Industrial and Organizational Psychology. Rand McNally, Chicago, IL, 1976, pp. 1297-1349.

Ludlum, D.A., "MIS Pros a Restless but Happy Crew," Computerworld, September 12, 1988, p. 1, 108-109.

Lysonski, S. "A Boundary Theory Investigation of the Product Manager's Role," Journal of Marketing, Vol. 49, Winter 1985, pp. 26-40.

Madden, J.F. "The Persistence of Pay Differentials: The Economics of Sex Discrimination," in L. Lanwood, A.H. Stromberg and B.A. Gutek (Eds.), Women and Work: An Annual Review. Sage Publications, Newbury Park, CA, Vol. 1, 1985, pp. 76-114.

Mai-Dalton, R.R. and Sullivan, J.J. "The Effects of Manager's Sex on the Assessment to a Challenging or Dull Task and Reasons for the Choice," Academy of Management Journal, Vol. 24, September 1981, pp. 603-612.

Marenghi, C. "There Are Cracks, but the Glass Ceiling is still mostly Intact," 
ComputerWorld, February 5,1992, p. 85.

Makridakis, S. and Wheelwright, S.C. Forecasting Methods for Management. Wiley,

New York, NY, Fifth Edition, 1989.

Morrison, A.M. and Von Glinow, M.A. "Women and Minorities in Management,"

American Psychologist, Vol. 45, No. 2, February 1990, pp. 200-208.

Morrison, AH., White,R.P., and Van Velsor, E. Breaking the Glass Ceiling: Can

Women Reach the Top of America's Largest Corporations? Addison Wesley, Reading, MA, 1987.

Mottaz, C.J., "Determinants of Organizational Commitment," Human Relations, Vol. 41 , No. 6,1988 , pp. $467-482$.

Nelton, S. and Berney, K. "Women: The Second Wave," Nation's Business, May 1987, pp. 18-27.

Niederman, F., Brancheau, J.C. and Wetherbe, J.C. "Information Systems Management Issues for the 1990s," MIS Quarterly, 1991, Vol. 15, No. 4, pp. 475-495.

Olson J.E. and Frieze, I.H. "Income Determinants for Women in Business," in A.H. Stromberg, L. Larwood and B.A. Gutek (Eds.), Women and Work: An Annual Review, Vol. 2, Sage Publications Newbury Park, CA, 1987, pp. 173-206.

Osajima, K. "Asian Americans as the Model Minority: An Analysis of the Popular Press Image in the 1960s and 1980s," in G.Y. Pkihiro, S. Hune, A.A. Hansen and J.M. Liu (Eds.), Reflections on Shattered Windows: Promises and Prospects for Asian American Studies, Washington state University Press, Pullman, WA, 1988, pp. 165-174.

Parasuraman, S. "Predicting Turnover Intentions and Turnover Behavior," Journal of Vocational Behavior (21), 1982, pp. 111-121.

Paul, R.J. "Role Clarity as a Correlate of Satisfaction, Job-Related Strain, and Propensity to Leave - Male vs. Female," The Journal of Management Studies, Vol. 11, 1974, pp. 233-245.

Pearl, A., Pollack, M.E., Riskin, E., Thomas, B., Wolf, E., and Wu, A. "Becoming a Computer Scientist," Communications of the $\mathrm{ACM}_{\perp}$ Vol. 33, No. 11, November 
1990, pp. 48-57.

Perry, N.J. "If You Can't Join 'em, Beat 'em," Fortune, September 21, 1992, pp. 58-59.

Porter, L.W., Crampon, W.J. and Smith, E.J. "Organizational Commitment and Managerial Turnover: A longitudinal Study," Organizational Behavior and Human Performance, Vol. 15, 1976, pp. 87-98.

Porter, L.W., Steers, R.M., Mowday, R.T. and Boulian, P.V. "Organizational Commitment, Job Satisfaction, and Turnover among Psychiatric Technicians," Journal of Applied Psychology, Vol. 59, 1974, pp. 603-609.

Powell, G.N. Women and Men in Management. Sage Publications, Newbury Park, CA, 1988.

Powell, G.N. and Butterfield, D.A. "The 'Good Manager': Did Androgyny Fare Better in the 1980's?" Group and Organizational Studies, Vol. 14, No. 2, 1989, pp. 216-233.

Rizzo, J.R., House, R.J. and Lirtzman, S.I. "Role Conflict and Ambiguity in Complex Organizations," Administrative Science Quarterly, Vol. 15, 1970, pp. 150-163.

Rogan, H. "Executive Women Find it difficult to Balance Demands of Job, Home," Wall Street Journal, October 30, 1984, pp. 35, 55.

Roche, G.R. "Much Ado about Mentor," Harvard Business Review, Vol. 57, No. 1, 1979, pp. 14-28.

Schwartz, F.N. "Management Women and the New Facts of Life," Harvard Business Review, Vol. 67, No. 1, January-February, 1989, pp. 65-76.

Schwartz, F.N. "Women as a Business Imperative," Harvard Business Review, Vol. 70, No. 2, March-April, 1992, pp. 105-113.

Shore, L.M. and Martin, H.J., "Job Satisfaction and Organizational Commitment in Relation to Work Performance and Turnover Intentions," Human Relations, Vol. 42 , No. 7, 1989, pp. 625-638.

Taylor, M.S. and Ilgen, D.R. "Sex Discrimination Against women in Initial Placement decisions: A Laboratory Investigation," Academy of Management Journal, vol. 24, 1981, pp. 859-865. 
Terborg, J.R. "Women in Management: A Research Review," Journal of Applied Psychology, Vol. 62, 1977, pp. 647-664.

Terborg, J.R. and Ilgen, D.R. "A Theoretical Approach to Sex Discrimination in Traditionally Masculine Occupations," Organizational Behavior and Human Performance, Vol. 13, 1975, pp. 352-376.

Thomas, D.A. and Alderfer, C.P. "The Influence of Race on Career Dynamics: Theory and Research on Minority Career Experiences," in M.B. Arthur, D.T. Hall and B.S. Lawrence (Eds.), Handbook of Career Theory. Cambridge University Press, Cambridge, U.K., 1989, pp. 133-158.

Truman, G.E. and Baroudi, J.J. "Gender Differences in the Information Systems Managerial Ranks: An Assessment of Discriminatory Practices," Working Paper, New York University, NY, 1992.

Tung, R. "Comparative Analysis of the Occupational Stress Profiles of Male versus Female Administrators,"Journal of Vocational Behavior, Vol. 17, 1980, pp. 344-355.

U.S. Department of Labor. Women in Management: Executives, Administrators, and Managers in the United States. Government Printing Office, Washington, DC, 1989.

U.S. Office of Personnel Management. Report on Minority Group and Sex by Pay Plan and Appointing Authority. Office of Personnel Management, Washington, DC, EPMD Report No. 40, March 31, 1989.

Van Sell, M., Brief, A.P. and Schuler, R.S. "Role Conflict and Role Ambiguity: Integration of the Literature and Directions for Future Research," Human Relations, Vol. 34, No. 1, 1981, pp. 43-71.

Viscusi, W.K. "Sex Differences in Worker Quitting," The Review of Economics and Statistics, Vol. 62, No. 3, August 1980, pp. 388-398.

Watson, R.T. "Influences on the IS Manager's Perceptions of Key Issues: Information Scanning and the Relationship with the CEO," MIS Quarterly, Vol. 14, No. 2, June 1990, pp. 217-231.

Williams, L.J. and Hazer, J.T. "Antecedents and Consequences of Satisfaction and 
Commitment in Turnover Models: A Reanalysis Using Latent Variable Structural Equation Methods,"Journal of Applied Psychology, Vol. 71, No. 2, 1986, pp. 219-231. 
Table 1: Relationship of Gender with Demographic Variables

A) Results of ANOVA

\begin{tabular}{lccc}
\hline Variables & Male & Female & Univariate \\
& $(\mathrm{N}=268)$ & $(\mathrm{N}=86)$ & $\mathrm{F}$ \\
& & \\
\hline
\end{tabular}

\begin{tabular}{lrrc} 
Age & 43.08 & 37.33 & $28.25^{\circ 00}$ \\
Organizational Tenure & 10.22 & 7.56 & $6.44^{\circ}$ \\
Job Tenure & 4.87 & 3.58 & $5.62^{\circ}$ \\
Number of Years in IS Field & 17.22 & 10.93 & $37.65^{\circ 00}$ \\
\hline
\end{tabular}

- $p \leq .05$

$\infty \quad p \leq .01$

$\infty \quad p \leq .001$ 


\section{B) Results of Chi-Square ${ }^{+}$}

Education:

Some College or less

Bachelor's Degree

Some Graduate School

Graduate Degree

Organizational Level:

Professional

Management

Salary

Below $\$ 25,000$

$\$ 25,000-\$ 34,999$

$\$ 35,000-\$ 44,999$

$\$ 45,000-\$ 54,999$

$\$ 55,000-\$ 64,999$

$\$ 65,000$ or above

90

58

45

73

82

184

47

39

24

19

16

27

$15.89^{\circ 00}$

$82 \quad 47$

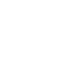

(2)

$\begin{array}{ll}0 & 24 \\ 8 & 19 \\ 5 & 16 \\ 3 & 27\end{array}$


Table 2: Job Type by Gender ${ }^{\star}$

\begin{tabular}{|c|c|c|c|c|c|}
\hline & \multicolumn{2}{|c|}{$\underline{\underline{\text { Male }}}$} & \multicolumn{2}{|c|}{ Female } & \multirow[t]{2}{*}{$x^{2}$} \\
\hline & $\mathrm{N}$ & Percentage & $N$ & Percentage & \\
\hline Job Type: & & & & & $21.15^{000}$ \\
\hline Programmers $(\mathrm{N}=47)$ & 28 & 59.6 & 19 & 40.4 & \\
\hline Systems Analysts $(\mathrm{N}=32)$ & 18 & 56.3 & 14 & 43.8 & \\
\hline Project Leaders $(\mathrm{N}=26)$ & 22 & 84.6 & 4 & 15.4 & \\
\hline IS Managers $(\mathrm{N}=186)$ & 153 & 82.3 & 33 & 17.7 & \\
\hline Other MIS Jobs ( $\mathrm{N}=37$ ) & 25 & 67.6 & 12 & 32.4 & \\
\hline Consultants $(\mathrm{N}=26)$ & 22 & 84.6 & 4 & 15.4 & \\
\hline Job Classification: & & & & & $19.78^{000}$ \\
\hline Technical (116) & 71 & 61.2 & 45 & 38.8 & \\
\hline Managerial (212) & 175 & 82.5 & 37 & 17.5 & \\
\hline Consulting (26) & 22 & 84.6 & 4 & 15.4 & \\
\hline Total & 268 & 75.7 & 86 & 24.3 & \\
\hline
\end{tabular}

* The values presented in this table are the number of males or females in a job type and the percentage of each from the number of IS employees for each job type.

$\infty \quad p \leq .001$ 


\section{Table 3: Results of ANOVA for Study Variables}

\begin{tabular}{|c|c|c|c|}
\hline \multirow[b]{2}{*}{ Work Variables } & \multicolumn{2}{|c|}{$\underline{\text { Subgroup Means }}$} & \multirow{2}{*}{$\begin{array}{c}\text { Univariate } \\
\mathrm{F}\end{array}$} \\
\hline & Male & Female & \\
\hline Organizational Level ${ }^{+}$ & 1.69 & 1.45 & $16.54^{000}$ \\
\hline Number of Promotion & 3.26 & 3.18 & .06 \\
\hline Average Time to Promotion & 5.09 & 3.71 & $5.25^{\circ}$ \\
\hline Promotability & 1.83 & 1.96 & 1.59 \\
\hline Salary & 4.21 & 3.19 & $35.29^{\circ 00}$ \\
\hline Boundary Spanning Activities & 3.34 & 2.80 & $12.83^{\circ 00}$ \\
\hline Job Satisfaction & 3.74 & 3.64 & .78 \\
\hline Organizational Commitment & 3.77 & 3.60 & $3.15^{\circ}$ \\
\hline Intention to Leave & 3.72 & 3.08 & $13.29^{000}$ \\
\hline
\end{tabular}

$+1=$ Professionals; $2=$ Management

- $p \leq .10$

$\infty \quad p \leq .01$

$\infty \quad p \leq .001$ 
Table 4: Results of ANCOVA for Study Variables*

\begin{tabular}{|c|c|c|c|}
\hline \multirow[b]{2}{*}{ Work Variables } & \multicolumn{2}{|c|}{ Subgroup Means } & \multirow{2}{*}{$\begin{array}{c}\text { Univariate } \\
\text { F }\end{array}$} \\
\hline & Male & Female & \\
\hline Organizational Level+ & 1.68 & 1.48 & $10.23^{\circ \infty}$ \\
\hline Promotability & 1.97 & 1.85 & .25 \\
\hline Average Time to Promotion & 4.52 & 4.22 & .34 \\
\hline Salary & 4.01 & 3.39 & $14.99^{\circ}$ \\
\hline Boundary Spanning Activities & 3.32 & 2.86 & $8.14^{\circ}$ \\
\hline Job Satisfaction & 3.72 & 3.67 & .15 \\
\hline Organizational Commitment & 3.76 & 3.62 & 1.61 \\
\hline Intention to Leave & 3.55 & 3.25 & $2.89^{\circ}$ \\
\hline
\end{tabular}

* Means adjusted for demographic covariates (i.e, age, organizational tenure, job tenure, number of years in the IS field, and education).

$+\quad 1=$ Professionals; 2 = Management.

- $p \leq .10$

- $p \leq .01$ 